\title{
MANUFACTURE OF EDIBLE YEAST EXTRACT FROM BREWERY WASTE YEAST
}

By

\section{G. Udaya Padmakumara}

Thesis submitted to the University of Sri Jayewardenepura as a partial fulfillment for the degree of

\author{
Master of Science \\ in
}

Food Science and Technology 


\section{DECLARATION}

The work in thesis was carried out by me as an in plant research at The Lion Brewery Ceylon Limited under the supervision of Prof (Mr) Authur Bamunuarachchi and Dr (Mr) K K D S Ranaweera, Faculty of Applied Sciences, University of Sri Jayewardenepura and Mr Saman Perera, The Head of Quality Assurance, The Lion Brewery Ceylon Limited. A report on this thesis has not been submitted to any other university for another degree.

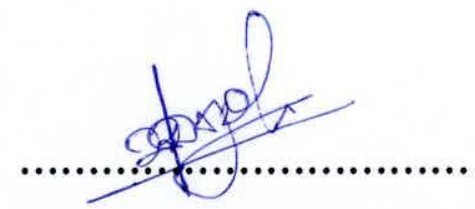

M G Udaya Padmakumara 
We, Prof Arthur Bamunuarachchi and Dr K K D S Ranaweera and

Saman Perera jointly here by certify that the statement in the preceding page made by the candidate is true and that this thesis is suitable for submission for the university for the purpose of evaluation

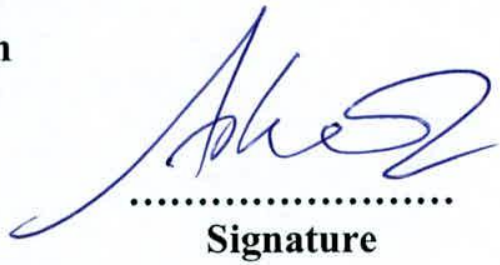

\section{Supervisor}

\section{Prof Arthur Bamunuarachchi}

Professor of Chemistry

Faculty of Applied Sciences

Department of Food Science and Technology

University of Sri Jayewardenepura

Nugegoda

\section{Supervisor}

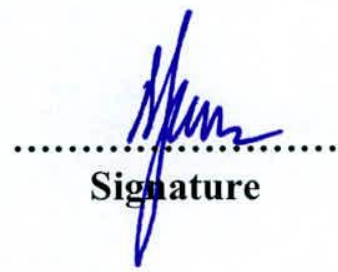

\section{Dr K K D S Ranaweera}

Head - Department of Food Science and Technology

Faculty of Applied Sciences

Department of Food Science and Technology

University of Sri Jayewardenepura

Nugegoda

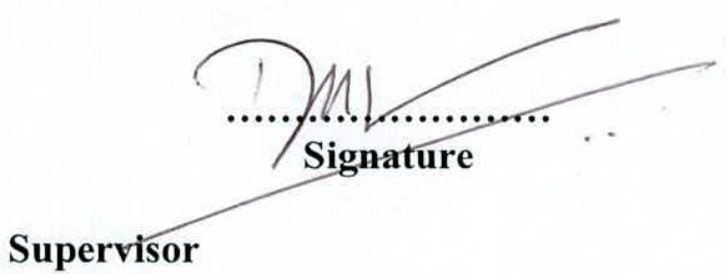

\section{Mr. Saman Perera}

The Head of Quality Assurance

The Lion Brewery Ceylon Limited

254, Colombo Road

Biyagama 


\section{Page}

Acknowledgement iv

Abstract

iv

\section{CHAPTER 01}

\subsection{INTRODUCTION}

Page

\subsection{Background}

1.1.1. Manufacture of Beer- The Brewing Process 1

1.1.2 Yeast Use and Waste Yeast Generation in Breweries 3

1.1.3 Amount and composition of brewery waste Yeast 3

1.1.4 Yeast Cell wall composition 5

1.2 Objectives 


\section{CHAPTER 02}

Page

\subsection{LITERATURE REVIEW}

2.1 General consideration of yeast extract

2.1.1 Definition of yeast extract

2.1.2 Production process of Yeast Extract 8

2.1.3 Uses of Yeast Extract 9

2.2 Preparation of Yeast Extracts

2.3 Methods used for Yeast Extract preparation

2.3.1 Autolysis

2.3.2 Thermolysis

13

2.3.3 Plasmolysis

13

2.3.4 Liquid Homogenization

2.3.5 Sonication

2.3.6 Enzymetic Method

14

2.3.7 Chemical Method

14

2.4 Evaluation of cell lysis 


\section{CHAPTER 03}

3.0 MATERIALS AND METHODS

Page

$\begin{array}{lll}3.1 & \text { Materials } & 16\end{array}$

$\begin{array}{llr}3.2 & \text { Equipments } & 16\end{array}$

$\begin{array}{lll}3.3 & \text { Reagents } & 17\end{array}$

$\begin{array}{lll}3.4 & \text { Method } & 17\end{array}$

$\begin{array}{lll}\text { 3.4.1 Sample collection } & 17\end{array}$

3.4.2 Yeast Cell Lysis Methods 18

3.4.2.1 Ohmic Heating Method 18

3.4.2.2 Sonication Method 18

3.4.2.3 Osmolysis Method 19

3.4.2.4 Thermolysis Method 19

3.4.2.5 Freeze Grinding Method 19

3.4.2.6 Acid Hydrolysis Method $\quad 19$

3.4.2.7 Autolysis Method 20

3.4.2.8 Enzymatic Lysis $\quad 21$

3.4.2.9 Combined Plasmolysis-Autolysis Method 21

3.4.2.10 Combined Method 22

3.4.3 Methods for Lysis Progress Measurements 22

3.4.3.1 Microscopic Observation 23

3.4.3.2 Protein Content Measurement 23 
3.4.4 Microbiological Analysis of the Test Product

3.4.5 Sensory Evaluation of Test Product 25

3.4.6 De-Bittering of Yeast Cream 27

CHAPTER 04

\subsection{RESULTS AND DISCUSSION}

4.1 Results

4.1.1 Direct microscopic counting method 28

4.1.2 Total Protein Method 34

$\begin{array}{lll}4.2 & \text { Product Characteristics } & 39\end{array}$

4.3 Nutritional Analysis of the Product 39

4.4 Microbiological analysis of Test Product 41

4.5 Sensory Evaluation of Test Product 42

4.5.1 Sensory Evaluation Results: In-house untrained Tasters $\quad 41$

4.5.2 Sensory Evaluation Results: In-house trained Tasters 41

4.5.3 Sensory Evaluation Results: External untrained Tasters $\quad 42$

4.6 Discussion

CHAPTER 05

CONCLUSIONS

REFERANCES 


\section{LIST OF TABLES}

Page

1. Effect of Ohmic Heating on Yeast Lysis 28

2. Effect of Ultrasound Wave on Yeast Lysis 28

3 Effectiveness of Osmolysis $\quad 29$

4 Effectiveness of Thermolysis $\quad 29$

$5 \quad$ Effect of Freeze grinding on Yeast cell damage 29

6 Effect of $\mathrm{HCl}$ concentration on Yeast cell damage 30

7 Effect of Temperature on Yeast Lysis 30

8 Effect of Salt Concentration on Yeast Lysis - (at $\left.45^{\circ} \mathrm{C}\right)$

$9 \quad$ Effect of Yeast Cell Density of the Autolysis Medium - (at $\left.45^{\circ} \mathrm{C}\right)$

10. Effect of $\mathrm{pH}$ on Yeast Lysis $-\left(\right.$ at $\left.45^{\circ} \mathrm{C}\right)$

11. Autolysis at $40^{\circ} \mathrm{C} \quad 32$

12. Autolysis at $45^{\circ} \mathrm{C} \quad 32$

13 Autolysis at $50^{\circ} \mathrm{C}$

14 Effect of Commercial Enzymes on Yeast Lysis - Enzyme Concentration 33

15 Combined Plasmolysis-Autolysis Method 33

16 Effect of Temperature on Yeast Lysis 35

17 Effect of Salt concentration on Yeast Lysis - (at $\left.45^{\circ} \mathrm{C}\right)$

18 Effect of Yeast concentration on Yeast Lysis - (at $\left.45^{\circ} \mathrm{C}\right)$

19 Effect of Salt concentration on Yeast Lysis - (at $\left.40^{\circ} \mathrm{C}\right)$

20 Effect of Salt concentration on Yeast Lysis (at $\left.45^{\circ} \mathrm{C}\right) \quad 35$

21 Effect Salt concentration at $50^{\circ} \mathrm{C} \quad 36$

22 Effect of $\mathrm{pH}\left(\right.$ at $\left.45^{\circ} \mathrm{C}\right) \quad 36$ 
23 Combined Plasmolysis-Autolysis Method

24 Effect of Commercial Enzymes on Yeast Lysis - Enzyme Concentration 37

25 Summary of the Results 38

26 Nutritional Analysis of Test Product 39

27 Typical nutritional Analysis of Market Product 40

28 Microbiological Quality of the Test Product 41 


\section{ACKNOWLEDGEMENT}

It is a great pleasure to place my sincere gratitude to Prof Authur Bamunuarachchi Professor of Applied Chemistry Department of Food Science and Technology University of Sri Jayewardenepura for being my supervisor and the guidance given me successfully complete the research project.

I deeply appreciate the valuable guidance given by my supervisor Dr K K D S Ranaweera, Head - Department of Food Science and Technology and The Coordinator, Food Science and Technology M Sc degree program

I would also like to thank Mr Saman Perera, Head of Quality Assurance, The Lion Brewery Ceylon Limited for being my supervisor and valuable guidance given to me.

I deeply appreciate the valuable guidance given by Dr Ajith de Alwis of University of Moratuwa.

My special thank goes to Mr Chan Liyanage, Director Technical, The Lion Brewery Ceylon Limited and all staff members of the Lion Brewery Quality Assurance department and all staff members of the Laboratory, Department of Food Science and Technology, University of Sri Jayewardenepura, for the assistance given to me during my project period. 


\title{
MANUFACTURE OF EDIBLE YEAST EXTRACT FROM \\ BREWERY WASTE YEAST
}

\section{BY: UDAYA PADMAKUMARA}

\begin{abstract}
Yeast extract is a well known material in the food industry. It is an essential item in numerous supplements, food ingredients, food flavourings, pharmaceuticals \& neutraceuticals, pet care products and microbiological media preparations.

Brewer's waste yeast is the main raw material in yeast extract preparations. Autolysis, enzymatic lysis, chemical and physical lysis are the widely used methods. However the exact processing conditions are kept secret by well known commercial producers.
\end{abstract}

Lion brewery generates approximately 720,000 liters $(668,572 \mathrm{~kg})$ of waste yeast slurry annually.

In the work presented here, an effort was made to develop a proteineous edible food of non animal origin by using brewery waste yeast through an economically feasible technology. Success will lead to the potential for a commercial product whilst eliminating an environmental hazard by disposal of yeast.

A number of lysis techniques and combinations of various lysis methods were tried out. Autolysis, combined plasmolysis-autolysis method, and enzymetic method were found to be the most effective methodologies for effective cell lysis. All these method delivered above 40 Microscopic Lysis Ratio. In combined plasmolysis-autolysis 
method yeast was first treated with $3 \% \mathrm{~V} / \mathrm{V}$ alcohol and allowed to plasmolyse at room temperature for $24 \mathrm{~h}$. Then sample was treated with $0.30 \%$ salt concentration and heated to $45^{\circ} \mathrm{C}$ and kept for $48 \mathrm{~h}$ and then heated to $80^{\circ} \mathrm{C}$ for $30 \mathrm{~min}$ to remove alcohol residue. This method delivered $45 \%$ MLR which was the highest yield obtained.

Purified product was analyzed for nutritional quality and found to be rich in protein, and Thiamin and microbiological results were satisfactory. Sensory evaluation revealed that there is a perceived significant difference in the test product over the similar product available in the market 


\section{CHAPTER 01}

\subsection{INTRODUCTION}

\subsection{Background}

\subsubsection{Manufacture Of Beer- The Brewing Process.}

\section{a. Brewing}

At the brewery the malt is cleaned, weighed and crushed to produce "grist". The grist is mixed with hot water in a "mash tun" (tank) and allowed to stand at a temperature which lets the starch from the malt to be converted into fermentable sugars. The mash is then transferred to a "lauter tun" where the liquid is separated from the grain residue. This sweet liquid is called "wort", (pronounced "wert".)

The wort is transferred to another tank called the "kettle" where liquid sugars are added and the mixture is boiled. During boiling, the protein material in the wort joins together to form "trub". The trub is removed by transferring the wort to a whirlpool.

\section{b. Fermentation}

After the trub is removed, the wort is cooled, and then transferred to a fermenter - a large closed vessel. Yeast is then added which converts the sugars into alcohol and carbon dioxide gas. During fermentation the yeast cells multiply many times. The carbon dioxide gas which is released is collected for use later. Fermentation continues until only non-fermentable sugars remain, when the fermenter is chilled to four degrees centigrade to stop fermentation. Yeast settles to the bottom of the vessel and from here it is removed for re-use, or sold and used to produce food products such as Marmite \& Vegemite. 


\section{c. Storage}

Once the yeast is removed the beer is passed from fermentation to storage vessels. During transfer the beer is cooled to minus one degree centigrade. Hop extract, which gives beer its characteristic bitter flavour, is added at this stage, which permits greater flavour control and enables the brewer to maintain a better taste consistency. The beer stays in storage at this temperature, and any material which might impair the appearance, flavour and shelf-life of the beer settles out.

\section{d. Filtration}

Following a set time in storage, carbon dioxide gas collected during fermentation is added to give beer its characteristic head and sparkling taste. The beer is then passed through a filtration system to remove surplus yeast and protein.

\section{e. Pasteurization.}

This is a process of heating and rapid cooling which prolongs shelf-life and destroys any bacteria or other organisms in the beer. Canned and bottled beers are pasteurized in their containers, while draught beer is pasteurized by means of a special heat exchanger called a flash pasteurizer.

\section{f. Packaging.}

The filtered and sparkling beer is packaged into bottles, cans and stainless steel casks, or kegs, ready for distribution. . 


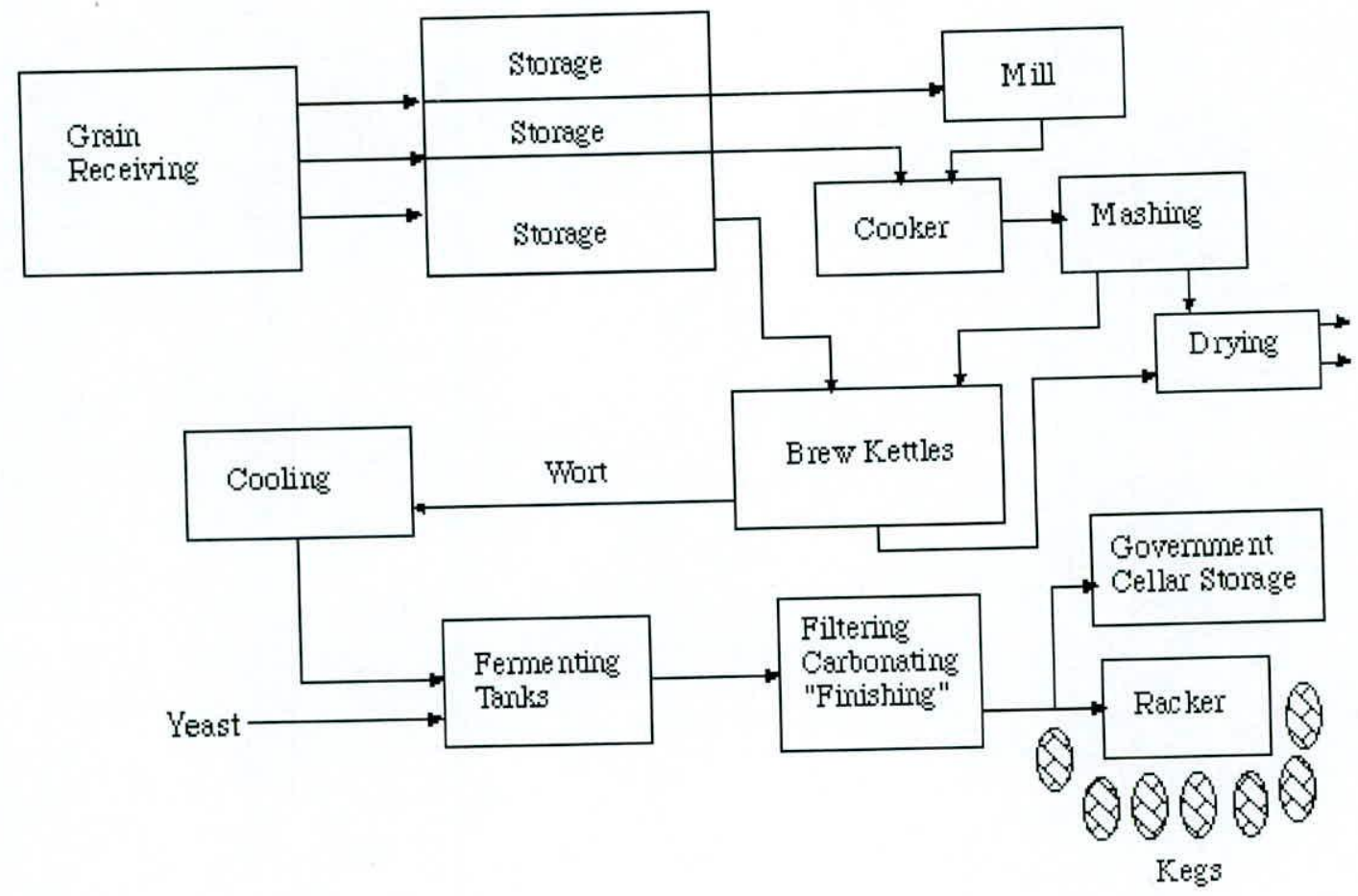

Figure 1.1 Brewing Process Flow Diagram

\subsubsection{Yeast Use and Waste Yeast Generation in Breweries}

During fermentation the yeast cells multiply many times and huge volumes of yeast cells are produced. At the end of the fermentation period, yeast settles to the bottom of the fermenting vessel and from here it is removed for re-use, or sold and used to produce food products such as Marmite \& Vegemite.

\subsubsection{Amount and composition of brewery waste Yeast}

Waste yeast is produced at a uniform rate with a constant composition in the brewery, although several types of yeast are used in the brewery they differ only in terms of settlability, thickness (number of yeast cells per $\mathrm{mm} 3$ ) and flavour producing characteristics. However the chemical constituents of brewers yeast remain more or less the same for different yeast strains 